\title{
WANITA KARIR DAN PENDIDIKAN ANAK DALAM RUMAH TANGGA
}

\author{
Harneny Pane \\ harnenypane1957@gmail.com
}

\begin{abstract}
ABSTRAK
Di abad XX kaum wanita telah banyak mengalami kemajuan. Dalam perkembangan modernisasi yang berdinding pada kelengkapan sarana dan fasilitas karena kaum wanita telah mensejajarkan diri dengan kaum pria. Banyak wanita yang telah menekuni berbagai bidang seperti bisnis,executive, politisi dan lain-lain.Dinamika wanita mengalami pergeseran nilai dan reformasi. Wanita tidak hanya merupakan istri atau merupakan pasangan dari suami dalam memimpin dan membina rumah tangga. Dengan bekerjanya si Istri membantu suami dalam mencari nafkah untuk menempatkan keluarga dalam kehidupan yang layak. Dampak positifnya perlu dikembangkan sedangkan dampak negatif perlu diminimalkan. Keberhasilan wanita karir dalam meningkatkan pendidikan anaknya dalam rumah tangga sangat menentukan oleh persepsi wanita karir itu dalam menghayati profesinya sebagai wanita karir.
\end{abstract}

\section{Kata kunci: Wanita karir, Pendidikan anak, Rumah tangga}

\section{PENDAHULUAN}

Di abad XX ini kaum wanita telah mengalami banyak kemajuan. Baik dibelahan bumi barat maupun dibelahan bumi timur, karena kaum wanita telah mensejajarkan diri dengan kaum pria. Banyak wanita yang telah menekuni berbagai bidang seperti : bisnis, eksekutif, politisi dan lain-lain.

Dalam perkembangan modernisasi yang berdinding pada kelengkapan kaum sarana dan fasilitas, dinamika kaum wanita mengalami pergeseran nilai dan reformasi yang semata-mata didasarkan pada ide kemudahan terhadap sosial ekonomi sebagai alternatif yang meningkatkan harkat dan martabat wanita afar tidak lagi menjadi si lemah. Wahana pemikiran ini dapat terjadi disebabkan pertumbuhan volume aktifitas kaum wanita dibidang profesi dan bisnis guna memantapkan kredibilitasnya sebagaia kaum wanita agar tidak dapat duduk sejajar dengan kaum pria. Di rumah tangga, isteri merupakan pasangan suami istri dalam memimpin dan membina rumah tangga. Jadi pada dasarnya isteri tidak bertanggung jaab dalam memenuhi kebutuhan primer dalam rumah tangga, dengan perkataan isteri tidak bertanggung jawab untuk memenuhi dan mencari nafkah.

Seorang isteri turut membantu suami dalam memenuhi kebutuhan, bukan hanya tekanan ekonomi tetapi dapat juga karena tuntutan modernisasi dan globalisasi yang menginginkan kehidupan yang lebih mudah. Turut sertanya isteri dalam membantu suami atau isteri melakukan aktivitas dalam berbagai kegiatan lebih dikenal dengan sebutan wanita karir.Dalam Al Qur'an surah Al An'am ayat 135, Allah berfirman. Artinya :"Dan katakanlah Wahai kaumku! Bekerjalah menurut profesimu atau kemampuanmu masing-masing. Sesungguhnya Aku adalah orang yang bekerja pula maka kamu akan mengetahuinya".

Allah SWT menciptakan wanita (isteri) untuk bertanggung jawab pada kehidupan dengan menganugerahkan kelebihan dan kekurangan yang terdapat dalam dirinya. Dibidang pendidikan anak, isteri bertanggung jawab dari pada suami. Hal ini disebabkan oleh faktor psykologis wanita dan dekatnya hubungan terhadap anak. Jadi, orang tua khususnya wanita merupakan pendidikan yang pertama dan yang utama dalam rumah tangga.

Secara umum tempat berlangsungnya pendidikan ada tiga yaitu : di rumah tangga, disekolah dan ditengah-tengah masyarakat. Pendidikan anak dirumah tangga pada dasarnya disesuaikan dengan kondisi rumah tangga itu sendiri. Pendidikan dirumah tangga disebut juga pendidikan informal, karena pendidikan itu diberikan secara tidak langsung tetapi berdasarkan pada kependidikan yang disesuaikan dengan tingkat kemampuan anak dalam menerimanya.

Semua pengalaman yang diterima oleh anak. Apakah itu pengalaman yang baik, atua pengalaman yang dikurang baik akan berpengaruh terhadap perkembangan kehidupan anak. Oleh sebab 
itu perhatian orang tua terutama ibu, seharusnya terfokus pada pendidikan anak sedini mungkin. Dengan demikian anak cukup berpengalaman dan latihan serta banyak menerima norma-norma baru dalam kehidupannya secara terus-menerus (proses sosialisasi anak), sehingga perkembangan kepribadiannya akan berjalan secara berkesinambungan.

Dengan bekerjanya si istri membantu suami dalam mencari nafkah untuk menempatkan keluarga pada kehidupan yang layak atau banyaknya aktifitas isteri diluar rumah, sudah barang pasti ada dampak positif dan negatifnya. Dampak positif perlu terus di kembangkan, sedangkan dampak negatifnya perlu diminimalkan. Dengan demikian tingkat kesejahteraan keluarga akan dapat ditingkat lagi, tetapi kewajiban dalam mendidik anak dalam membina rumah tangga tidak terabaikan.

Pengaruh negatif yang sangat dominan pada wanita karir adalah ketelitian fisik atau pshikis dapat menyebabkan rasa cepat marah, sehingga wanita karir akan kurang bergairah ketika berada dirumah. Namun dari segi positifnya, yaitu dapat mengatasi kesulitan finansial. Dengan demikian akan berpengaruh terhadap pengadaan alat-alat pendidikan dan alat-alat permainan. Segi positif ini bila tidak didukung oleh pembinaan dan perhatian serta kasih sayang dari orangtua, akan berakibatkan fatal bahkan merusak perkembangan anak itu sendiri.

\section{TUJUAN PENELITIAN}

Tujuan penelitian ini adalah mengetahui arah dan batasan penulisan yang akan diamati agar tetap proporsional sekaligus untuk menetapkan permasalahan pokok yang hendak dikaji (dianalisa) dalam tulisan ini. Maka Penulis merumuskan masalah dalam karya ilmiah ini adalah bagaimana persepsi wanita karir terhadap pendidikan anak dalam rumah tangga.

\section{OBJEKTIF PENELITIAN}

Wanita karir dan pendidikan anak dalam rumah tangga Isteri adalah pasangan suami dalam mengayuh bahtera rumah tangga. Dengan demikian isteri merupakan mita (partner) suami dalam rumah tangga.

\section{TINJAUAN PUSTAKA}

Wanita karir berasal dari dua kata, yaitu, wanita dan karir. Dalam kamus umum Indonesia, (Poerwaqdarminta, 1985 : 277) disebutkan, "Wanita karir adalah orang perempuan atau kaum putri”. Dan "Karir adalah kemajuan dalam kehidupan atau perkembangan dan kemajuan dalam pekerjaan, jabatan dan lain-lain". Bila dipadukan kedua pengertian itu, maka diperoleh pengertian dari wanita karir adalah "Orang- perempuan atau kaum puteri yang mengalami kemajuan dan perkembangan dalam pekerjaan dan jabatan". Lusia Susanto (2013) menyebutkan, wnaita karir adalah wanita yang bekerja sehari-hari untuk menjalankan tugas praktis sehingga mengalami perkembangan dalam pekerjaan". Dari kedua pendapat tersebut dapat disimpulkan bahwa wanita karir adalah wanita yang bekerja, baik dibidang profesi yang menghendaki persyaratan-persyaratan tertentu maupun pekerjaan yang tidak menuntut adanya persyaratan tertentu guna mengembangkan diri untuk mendapatkan kemajuan. Penulis cenderung berpendapat bahwa wanita karir itu adalah wanita yang menuntut adanya ketrampilan tertentu untuk dapat mengembangkan diri dalam mencapai kemajuan.

Dalam Garis-Garis Besar Haluan Negara 1993 prihal peran wanita dinyatakan sebagai berikut."wanita sebagai mitra sejajar pria harus lebih dapat berperan dalam pembangunan dan kehidupan bermasyarakat, berbangsa dan bernegara serta ikut melestarikan nilai pancasila. Oleh karena itu, perlu terus dikembangkan kemampuannya melalui peningkatkan pengetahuan, keahlian dan keterampilan, dengab tetap memperhatikan kodratnya serta harkat dan martabatnya kaum wanita". Sedangkan Dadang Hawari (2004 : 40) menyebutkan, "Wanita yang bekerja dapat dibagi dalam tiga kategori, yaitu : Wanita yang berkeluarga dan bekerja, Wanita yang pernah berkeluarga dan bekerja, Wanita yang belum pernah berkeluarga dan bekerja. Jadi masing-masing bekerja tersebut mempunyai problematika sendiri-sendiri, yaitu : sebagai isteri, sebagai janda dan single. Bagi isteri yang bekerja umumnya terdapat dua motivasi yang mendasari yaitu : untuk mengembangkan karir dan turut mencari penghasilan disamping penghasilan suami.

A.M Saefuddin (1994 : 36) menyebutkan : Ada beberapa dampak psikologis yang dapat menganggu keharmonisan hubungan suami isteri antara lain : Suami sering menngeluh bahwa sejak isterinya turut bekerja dan berpenghasilan, dirasanya wibawa dirinya terhadap isteri menurun. Hal ini 
dikarenakan isteri sudah belajar mandiri dan mengulangi ketergantungan pada suami. Bagi isteri yang berkatit dan berpenghasilan jauh lebih tinggi dari suami, dapat menimbulkan adanya perasaan rendah diri dan rasa cemburu dari suami. Peran suami sebagai pencari nafkah keluarga dapat berbalik manakala suami bekerja lagi sedangkan isteri masih tetap bekerja. Kondisi seperti ini dapat menyebabkan suami merasa rendah diri, harga dirinya menurun, wibawa suami terhadap isteri dan anak - anaknya berkurang bahkan kemungkinan kendali keluarga dipegang oleh isteri. Dalam kondisi posisi suami seperti contoh diatas, maka berbagai komplikasi psikologis dapat dialami oleh suami, sehingga suami selalu mengemukakan berbagai keluhan dalam bentuk kecemasan, depresi dan gangguan psikosomatik atau dapat juga dalam bentuk sikap, seperti menjadi dinding, pencemburu, pemarah, kasar dan sampai menyakiti fisik isterinya.

Menurut Seto Mulyadi (1994), "Peranan baby-sitter hanya berfunngsi membantu saja. Bila orang tua menyerahkan $100 \%$ pendidikan anaknya kepada baby-sitter, dapat menimbulkan berbagai kemungkinan. Misalnya rusaknya hubungan komunikasi antara ibu dan anak, bahkan orang tua merupakan makhluk asing bagi anak". Dalam hubungan dengan tanggung jawann, penulis mengemukakan sebuah hadist. Artinya : “Tiap-tiap kamu adalah pemimpin, dan tiap-tiap pemimpin bertanggung jawab terhadap hal-hal yang dipimpinnya (HR. Bukhari dan Muslim 1976 : 12)' Dari hadist diatas dapat kita ketahui bahwa setiap manusia merupakan pemimpin yang dimintai pertanggung jawaban oleh Allah S.W.T. Seorang suami merupakan pemimpin dalam keluarganya, akan dimintai pertanggung jawaban dalam kepemimpinanya. Seorang isteri adalah pemimpin dalam rumah tangga suaminya, akan dimintai pertanggung jawaban dalam kepemimpinannya itu.

Pendidikan berasal dari kata didik yang diberi konflik ke-an, yang berarti segala sesuatu yang sifatnya mendidik. Ki hajar Dewantara (1965 : 47) menyebutkan,"pendidikan adalah daya upaya untuk memahami bantuan pada kodrat anak agar mereka sebagai individu maupun anggota masyarakat dapat mencapai keselamtaan dan kebahgian hidup lahir batin". Ahmad D. Rambe (1974 : 20) menjelaskan, “ pendidikan adalah bimbingan atau pemimpin secara sadar oleh pendidik terhadap perkembangan jasmani dan rohani terdidik menuju terbentuknya kepribadian utama". Dari dua pendapat diatas dapat disimpulkan bahwa pendidikan itu merupakan usaha sadar yang dilakukan pendidik dan pserta didik untuk saling membantu dan mengembangkan jasmani dan rohani anak guna tercapainya suatu tujuan tertentu. Jelaslah bahwa dalam dunia pendidikan itu terdapat empat hal pokok, yaitu : peserta didik,pendidik,tujuan dan media pendidikan.

\section{METODE PENELITIAN}

Penelitian ini melakukan survey langsung kelapangan dan membagikan kuisoner yang isinya berkaitan dengan wanita karir dalam mendidik anak. Analisis data menggunakan deskriftif. Hal ini akan dapat diketahui melalui pendidikan dalam rumah tangga. Perkembangan kehidupan anak harus ditinjau dari berbagai segi, karena pertumbuhan anak meliputi berbagai aspek antara lain : pertumbuhan biologis, psikologis dan paedogogis. Tiga aspek pertumbuhan anak meliputi berbagau aspek antara lain : pertumbuhan biologis, psikologis dan paedogogis. Tiga aspek pertumbuhan itu mestinya mendapat perhatian sepenuhnya dari orang tua. Kegagalan dalam memperhatikan salah satu aspek pertumbuhan dapat menimbulkan kefatalan dalam perkembangan kehidupan anak. Perkembangan psikologis terdisi dari beberapa fase.

\section{HASIL PENELITIAN}

Hasil penelitian diperoleh bahwa Setiap fase memerlukan perhatian sepenuhnya dari orang tua sehingga anak meraskan suasana berkembang secara wajar dibawah kasih sayang orang tua. Pada umumnya pendidikan anak dalam rumah tangga lebih banyak dikendalikan oleh ibu. Dalam mendidik si anak, ibu harus mampu berbuat untuk:

\section{a. Membina Komunikasi Dengan Anak}

Komunikasi secara terbuka antara orang tua dengan anak sangat penting untuk membina saling pengertian dan keakraban. Membina hubungan baik antara orang tua dengan anak bukanlah merupakan suatu keterikatan atau paksaan, tetapi dilaukan berdasarkan rasa kasih sayang, kebersamaan, perhatian dan saling menghormati. Hubungan baik anatara anak dengan orang tua tidak dapat dicapai dengan cara lain kecuali harus dapat berperan sebagai 
teman, yaitu saling menyayangi, menyukai, memahami dan santai bersama. Agar anak mau berkomunikasi dengan orang tua harus mau mendengarkan anak. Dengan kata lain berbicaranya anak pada orang tua berarti anak telah melimpahkan segala unek-uneknya kepada orang tua. Hal ini merupakan suatu proses untuk menangkap dan memahami pesan yang disampikan anak melalui kata-kata. Anak mau berkomunikasi dengan orang tua apabila anak merasa bahwa orang tua mendengarkan apa yang disampaikannya. Ada beberapa hal yang harus diperhatikan oleh orang tua pada saat berkomunikasi dengan anak, yaitu: Tunjukkan rasa tertarik pada pembicaraan anak, dengarkan pembicaraan anak dengan penuh konsentrasi, jangan membagi perhatian terhadap pekerjaan yang lain. Sabar dan biarkan serta beranikan anak untuk berbicara. Perhatikan sikap anda sebagai orang tua, terutama pada saat menyampaikan pesan. Usahakan agar anda bisa menghayati isi pembicaraan anak. Bantulah anak untuk menjelaskan atau menghubung kan suatu pengalaman dengan menggunakan katakata anda sendiri. Anda harus mampu merefleksikan perasaan seperti apa yang telah dibicarakan selanjutnya. Perhatikanlah pesan yang tidak disampaikan melalui kata-kata.

\section{b. Menanamkan Disiplin Kepada Anak}

Menanamkan disiplin biasanya menjadi tujuan pokok dalam membina anak. Terdapat berbagai cara dalam menanamkan kedisiplinan, namun banyak yang kurang tepat dan kurang efektif sehingga hanya sedikit hasil yang diperolehnya. Tipe paling efektif adalah dengan menggunakan pendekatan yang positif, misalnya : dengan menakut-nakuti, memberikan hukuman, memberikan sanksi dan sebagainya.

Pada pendekatan positif, perhatian dalam memdidik lebih ditekankan pada sikap meneyesuaikan diri terhadap anak, misalnya : menunjukan rasa hormat, menghargai dan mendorong. Pandangan terhadap anak-anak seolah-olah dianggap sebagai teman, dengan demikian mereka merasa biasa hidup bersama anda. Sebaliknya pendekatan negatif dengan memberikan hukuman secara fisik atau psikis akan berakibat buruk. Teknik pemberian hukuman dapat berupa penghinaan, ejekan, sindrian, teriakan atau pukulan terhadap anak atau bahkan mencela anak. Hal ini dapat menimbulkan rasa rendah diri dan biasanya hanya untuk mencegah tingkah laku anak yang tidak wajar dan membahayakan.

\section{c. Memberi Teladan Pada Anak}

Orang tua sebagai teladan mempunyai pengaruh yang kuat dalam memberikan pendidikan terhadap anak. Anak akan menirukan apa yang dilakukan orang lain, terutama orantuanya. Memebrikan tauladan merupakan cara yang efektif dari pada bahasa, karena bisa memberikan gambaran dan isyarat yang jelas untuk dapat ditiru. Pengetahuan anak mengenai sikap orang tua. Oleh karena itu perlu disadari dan diperhatikan agar orang tua dapat memberikan teladan yang baik dan benar.

Orang tua yang bijaksana, tentu akan berusaha memberikan yang baik pada anaknya dengan berbagai cara misalnya : menghadapi problema setiap hari dengan baik, bijaksana, sabar, dan dapat mengendalikan emosi, mengerjakan tugas dengan tekun, mengahrgai hasil karya orang lain, menunjukan pandangan hidup optimis, membuat kegiatan-kegiatan yang menyenangkan, tidak meneyesali hal-hal yang telah berlalu, mempererat hubungan dengan anak, memperbanyak pengetahuan tengtang cara mendidik anak dengan jalan membaca dan sebagainya.

\section{d. Membentuk Rasa Percaya Diri}

Seorang anak yangs edang tumbuh dan berkembang membutuhkan pengakuan dari luar untuk dapat memebentuk kepercayaan dirinya. Sesuai dengan tingkat usianya, anak adlah figur yang berada dalam posisi belajar dan mencoba. Karena rasa kasih sayang orang tua, terkadang orang tua sering bersikap emosional sehingga cenderung terlalu mengawasi dan melindungi. Disini peran orang tua sangat penting, karena kasih sayang orang tua terhadap anak selalu membawa pesan bahwa anak itu bersifat kompeten.

Orang tua harus memberikan kesempatan kapada anaknya untuk mencoba berdisi sendiri, mendorong anak untuk melakukan sesuatu tanpa rasa bersalah, sehingga ia punya keyakinan diri. Bahkan membantu dengan senang hati unutk menambah semangat untuk 
melakukan apa yang dianggapnya positif. Dalam mengatasi kecemasan, hasrat marah baik pikiran dan fantasi yang menakutkan juga diperlukan orang tua. Orang tua harus dapat berperan ganda, menanggapi perasaaan frustasi, kemarahan dan kecemasan anak secara simpatik dan pada waktu yang bersamaan dapat menyakinkan anak bahwa pikiran yang frustasi tidak dapat terjadi dalam kenyataan, sehingga batin anak menjadi tetap tenang.

\section{e. Wanita Karir dan Pendidikan Anak dalam Rumah Tangga}

Banyak pasangan muda masa kini, baik suami maupun isteri sama-sama bekerja. Baik kaum wanita yang tidak bekerja, banyak juga yang aktif dalam kegiatan sosial atau organisasi wanita baik dikalangan tinggi, maupun kalangan menengah keatas, para wanita bekerja pada umumnya mempunyai keinginan untuk mencapai jenjang karir yang setinggi mungkin. Bagi kalangan menengah kebawah, kebanyak suami untuk memenuhi kebutuhan hidup rumah tangga. Lusia Sutantu (2004 : 35) menyebutkan, ada beberapa hal pokok yang harus diperhatikan oleh wanita pekerja, yaitu :Dia harus mempunyai kepribadian yang baik, memiliki ketrampilan sesuai dengan tugas yang dipercayakan kepadanya, berkemampuan untuk dapat bekerja sendiri dan memiliki loyalitas terhadap perusahaan. Dia harus jujur, disiplin, rajin dan penuh tanggung jawab. Dia harus teliti dan peka terhadap lingkungan dimana ia berada serta berpenampilan rapi. Dia harus tahu dimana posisi dan kedudukannya. Dia harus tahu kewajiban serta hak-haknya diperusahaan. Bila ia bukan seorang yang cerdas, sebaiknya tetap mempunyai naluri yang tajam, peka terhadap situasi yang dihadapi, dan dapat berkomunikasi dengan baik. Dia harus seorang pribadi dengan banyak misi dan kalau mungkin mempunyai wawasan yang luas terhadap bidangnya. Secara manusia ia harus memiliki penguasaan yang baik terhadap lingkungan, karena walaupun ia menguasai secara teknis pelaksanaan tugasnya, namun tanpa pengenalan lingkungan yang baik, ia tidak mungkin dapat berhasil dengan baik didalam melaksanakan tugasnya.Dia harus belajar dari pengalaman, namun belajar untuk meningkatkan pengetahuan dan keterampilan.

Bagi wanita pekerja, disamping berusaha untuk memenuhi apa yang diharapkannya oleh perusahaan tempat ia bekerja, masih ada hal lain yang perlu diperhatikan, seperti tuntutan lingkungan. Tuntukan lingkungan ini bervariasi maka sebagai wanita harus mampu memenuhi tuntutan tersebut yaitu dengan berperan sebagai : Isteri yang baik bagi suami, Ibu yang bertanggung jawab abagi anak-anaknya, Wanita sosial yang baik dimasyarakat. Wanita pekerja yang berdedikasi. Mengingat wanita harus berperan ganda, maka harus ada keseimbangan/keharmonisan anatara wanita sebagai ibu rumah tangga bila dirumah dan wanita sebagai pekerja bila ia bekerja. Untuk mencapai keseimbangan tidaklah suatu hal yang mudah, namun harus berupaya semaksimalnya. Keluarga merupak kelompok sosial dalam kehidupan manusia. Dilingkungan rumah tangga, setiap anggota rumah tangga menyatkan dirinya sebagai makhluk sosial dalam berinteraksi dengan kelompoknya. Tanpa kelompok, manusia tidak akan mampu hidup. Berbeda dengan hewan yang mampu hidup tanpa membina kelompok sosial. Soerjono Soekamto (2003 : 97) menjelaskan. Memang apabila manusia dibandingkan dengan makhluk- makhluk hidup lainnya seperti hewan, dia tidak akan hidup sendiri. Seekor anak ayam misalnya, walaupun tanpa induknya mampu unutk mencari makan sendiri, demikian halnya hewan-hewan lainnya seperti kucing, anjing, harimau, gajah dan sebagainya. Manusia tanpa manusia lainnya pasti akan mati. Bayi misalnya harus diajari makan, berjalan, bermain dan lain sebagainya. Jadi sejak lahirnya manusia harus berhubungan dengan menusia lainnya. Lagi pula manusia tidak dikaurniai oleh Tuhan dengan alat-alat pisik yang mampu untuk hidup mandiri.

Di lingkungan keluarga, anak pertama kali melakukan interaksi sosial terhadap anggota keluarga sehingga individu itu dapat dipengaruhi secara total atau terkadang kelompok itu dipengaruhi oleh individu. Oleh sebab itu khusus di lingkungan rumah tangga, yang paling bertanggung jawab untuk mendidik anak adalah orang tua, yaitu ayah dan ibu. 


\section{KESIMPULAN}

Wanita (Ibu) sangat menentukan terhadap keberhasilan pendidikan anak dalam rumah tangga. Wanita karir dapat berdampak positif terhadap keberhasilan pendidikan anak apabila si Ibu dapat menempatkan diri sebagai Ibu dan wanita karir, dapat berdampak negatif pada pendidikan anak apabila si Ibu tidak mampu menempatkan peran sebagai Ibu dan sebagai wanita karir.

\section{RUJUKAN}

Departemen Agama Republik Indoensia, 1996, Terjemahan Al-Qur'an, Jakarta, Al-Ma'rif Dewantara Kumpulan Karyawan KH. Dewantara, Yogyakarta, Majelis Luhur, Taman Siswa.

Effendi Uchjana, Onong, (1981), Komunikasi dan Modernisasi, Alumni Bandung.

Hadi S, 1998, Statistika II, Jakarta, Fakultas UGM.

Hawari, D, 1994, Wanita Pekerja dan Problematiknya, Suara Mesjid Jakarta, Purwadarminta, 2005, Kamus Bahasa Indonesia, Bandung, PT. Al-Ma'rif.

Sukamto, S, 2007, Sosiologi Suatu Pengantar, Jakarta, Universitas Indonesia.

Soetanto L, Martabat Wanita sebagai Pekerja, Harian Simponi, Jakarta.

Akmalsutja,blogspot.com,2010/05, Dampak Wanita Karier Terhadpa Pendidikan Anak. 